\title{
A questão antropológica na Educação quando o tempo da barbárie está de volta
}

\section{The Education anthropological question when barbarism is back}

\author{
Bernard Charlot*
}

\begin{abstract}
RESUMO
Por um lado, indícios de volta da barbárie; por outro, debates sobre os direitos dos animais, de robôs e até de extraterrestres. Hoje, observa-se uma indeterminação crescente quanto à definição do que é um ser humano, ou seja, quanto à questão antropológica. Essa é uma questão fundamental para quem se interessa pela educação. O que os discursos sobre a educação nos dizem sobre o homem? Em um primeiro momento, interrogam-se as pedagogias "tradicionais" e "novas", que repousam sobre discursos sobre a natureza humana. A seguir, constata-se que não existe hoje uma pedagogia "contemporânea", com uma dimensão antropológica, mas bricolagens pedagógicas numa lógica socioeconômica da performance e da concorrência. Depois, esboça-se, do ponto de vista antropológico, a análise de alguns discursos contemporâneos, sobre a "qualidade da educação", a "neuroeducação", a "cibercultura", o "transhumanismo". Enfim, alguns ensinos da ciência contemporânea sobre o cérebro, os genes e a evolução possibilitam entender que o ser humano é uma aventura singular e coletiva e sonhar em uma educação da solidariedade e da dignidade que contribua com a luta contra a barbárie.

Palavras-chaves: Educação. Barbárie. Contemporaneidade. Antropologia. Ciência.
\end{abstract}

\footnotetext{
ABSTRACT

On the one hand, evidences that barbarism is back; on the other hand, debates on the rights of animals, robots and even aliens: today there is an increasing indetermination about the definition of what a human being is,

* Universidade de Paris X, França. Professor Emérito da Universidade de Paris 8. Professor Visitante na Universidade Federal de Sergipe. João Pessoa, Sergipe, Brasil. E-mail: bernard.charlot@terra.com.br_http://orcid.org/0000-0001-8725-4238
} 
that is, on the anthropological question. This is a fundamental issue for anyone interested in education. What do the discourses about education tell us about human being? At first, we question the "traditional" and "new" pedagogies, which rest on discourses about human nature. Next, we observe that there is no "contemporary" pedagogy, with an anthropological dimension, but pedagogical bricolages in a socioeconomic logic of performance and competition. Then, the analysis of some contemporary discourses on the "quality of education", "neuroeducation", cyberculture and transhumanism is sketched out from the anthropological point of view. Finally, some teachings of contemporary science on the brain, genes and evolution make possible to understand that the human being is a singular and collective adventure and dreaming of an education of solidarity and dignity that contributes to the fight against barbarism.

Keywords: Education. Barbarism. Contemporaneity. Anthropology. Science.

"Bar-bar-bar": com essa onomatopeia de desprezo, os gregos exprimiam a forma de falar dos persas e assim nasceu a palavra "bárbaro". Ela se generalizou e acabou designando, de maneira pejorativa, quem não é grego e, portanto, não é civilizado. O bárbaro tem aparência humana, mas é radicalmente outro que não um verdadeiro ser humano e, logo, pode ser tratado como um objeto; em particular, ele pode ser escravizado. Esse foi o assunto da chamada Controversa de Valladolid, na Espanha, em 1550-1551: os índios do Novo Mundo são filhos de Deus a serem evangelizados ou, estando em um estado natural de barbárie, podem ser submissos ao trabalho forçado? Os teólogos reunidos pelo Imperador Carlos V nunca decidiram, mas, em 1573, uma lei proibiu a escravidão e o uso da violência contra os índios. Paradoxalmente, essa decisão acelerou a escravização nas colônias sul-americanas: os colonizadores importaram negros da África, a respeito dos quais ninguém negou que pudessem ser escravizados.

$\mathrm{O}$ assunto em debate em Valladolid e em outros momentos da história é a definição do ser humano e dos seus direitos inalienáveis enquanto ser humano. O processo de civilização consistiu em ampliar o campo da humanidade e dos direitos humanos: proibição da escravidão e do trabalho infantil, direito ao voto pelas mulheres, inclusão social e pedagógica das pessoas com deficiência, luta contra a discriminação étnico-racial, religiosa, de gênero etc. De tal modo que passou a ser considerado bárbaro quem não reconhecia os direitos fundamentais de todos os seres humanos e apelava para a violência contra uma categoria de homens (ou de mulheres) ${ }^{1}$. Essa barbárie nunca desapareceu por completo,

1 Neste artigo, homem significa ser humano, seja qual for o gênero. 
como atestam a Primeira Guerra Mundial, o nazismo, os golpes militares, mas, nas últimas décadas - nos anos 1960 na Europa, 80 na América do Sul -, cresceu o sentimento de que o mundo se tinha livrado da barbárie. Hoje, porém, multiplicam-se os indícios de sua volta, inclusive no Brasil: intolerância religiosa ou nacionalista, ódio político, terrorismo que mata até crianças, assassinatos de jornalistas ou candidatos a uma eleição, elogio à tortura, separação entre pais e filhos migrantes, feminicídios etc.

Ao mesmo tempo, a questão da definição do ser humano é levantada a respeito de novas categorias: os animais, os robôs e eventuais extraterrestres. Em 2011, em uma floresta da Indonésia, o fotógrafo David Slater descuidou de sua câmera e um macaco, apertando o botão, tirou uma selfie dele, sorridente. Essa selfie do macaco fez sucesso na internet, mas, em 2015, uma organização de defesa dos animais pediu à Justiça que o macaco fosse declarado dono da imagem e recebesse os direitos autorais, alegando que o trabalho tinha sido feito por ele. Afinal de contas, depois de um longo processo e apesar de um acordo em que Slater aceitou doar $25 \%$ dos futuros direitos autorais a instituições de caridade protegendo os macacos, a Justiça, em 2018, decidiu que a lei sobre direitos autorais era reservada aos humanos e indeferiu o requerimento da associação. Mas a ideia de que somos bárbaros com os animais e devemos respeitar os direitos fundamentais deles começa a ser sustentada com insistência por associações. Se pode discutir sobre os direitos de macacos, por que não abrir também um debate jurídico sobre robôs? Em 2016, a Comissão dos Assuntos Jurídicos do Parlamento europeu recomendou a criação de uma personalidade jurídica dos robôs, com direitos e deveres. Por mais estranha que seja essa ideia, ela não é absurda. Com efeito, logo serão produzidos robôs androides fingindo emoções, companheiros de vida e até parceiros sexuais: poderemos maltratá-los de acordo com nossos próprios humores efêmeros ou eles terão direito a uma forma de respeito? Por fim, podemos também levantar uma questão a respeito de eventuais extraterrestres, como já fez o Observatório do Vaticano: se descobrirmos extraterrestres, será que deveremos considerar que eles também têm uma alma que foi redimida por Jesus?

Por um lado, volta da barbárie; por outro, debates sobre extensão dos direitos humanos além de Homo sapiens: o que ambos os casos têm em comum é uma indeterminação crescente quanto à definição do que é um ser humano, ou seja, quanto à questão antropológica. No campo da Educação, o que temos a dizer sobre esse assunto, já que podemos considerar a priori que a questão " $\mathrm{O}$ que é um ser humano?” é fundamental para quem se interessa pela educação? O que a pedagogia e, de forma mais ampla, os discursos sobre a educação, nos dizem sobre o homem? Essa será a nossa questão central neste texto. Em um primeiro momento, interrogaremos as pedagogias clássicas, sejam elas catego- 
rizadas como "tradicionais" ou "novas". A seguir, perguntaremos se existe hoje uma pedagogia "contemporânea", propondo um ideal humano com base em que possamos pensar as crianças e sua educação. Depois, esboçaremos, do ponto de vista antropológico, a análise de alguns discursos contemporâneos, sobre a "qualidade da educação", a "neuroeducação", a "cibercultura", o "transhumanismo". A seguir, procuraremos na ciência contemporânea algumas indicações sobre o que é um ser humano e proporemos algumas reflexões sobre o que essa longa viagem (às pressas...) pode nos ensinar sobre a educação do ser humano e sua eventual contribuição à luta contra a barbárie².

\section{A definição da natureza humana nas pedagogias "tradicional" e "nova"}

A pedagogia "tradicional" e a pedagogia "nova" repousam sobre bases antropológicas: elas definem uma natureza humana e determinam a partir dela como deve ser a educação. Aliás, as expressões "pedagogia tradicional" e "pedagogia nova" são designações muito amplas, uma vez que cada uma delas remete a formas pedagógicas bastante diferentes e, de fato, é apenas com referência a duas representações diferentes da natureza humana que é pertinente organizar assim a pedagogia clássica em "tradicional" ou "nova".

Na sua versão religiosa, a pedagogia tradicional considera que a criança é naturalmente corrupta (SNYDERS, 1965; CHARLOT, 2013a). Com efeito, a natureza humana foi corrompida pelo pecado original e, logo, a criança nasce corrupta. Qual seu crime, pergunta o bispo Bossuet, no século XVII? "Ele é filho de Adão, esse é seu crime", ele responde (apud SNYDERS, 1965, p. 192)³. Essa ideia de corrupção natural da criança tinha tanta força naquela época que até Rollin, que representa a universidade, diagnostica na criança "uma inclinação natural para o mal" (CHARLOT, 2013a, p. 177). Contudo, a Bíblia ensina também que Jesus veio para salvar os homens e, além do mais, a corrupção ainda não está profundamente enraizada na alma da criança. Portanto, podemos lutar contra a natureza corrupta da criança, pela regra, pela norma, pela disciplina,

2 Este artigo pretende apenas apresentar em português, antecipada e resumidamente, algumas conclusões de um livro que está sendo escrito em francês. A base deste texto é uma conferência (não publicada) ministrada no dia 20/09/2018 no Colóquio Internacional Educação e Contemporaneidade (EDUCON XII), na Universidade Federal de Sergipe.

3 Tradução nossa, como sempre é o caso quando citamos em português um texto cujo título aparece em outra língua nas referências finais. 
resumidamente: pela educação. A pedagogia tradicional é, fundamentalmente, uma pedagogia da Norma contra o Desejo - logo, contra o corpo e a emoção, que são as fontes do desejo.

A versão laica e iluminista da pedagogia tradicional, a de Kant, de Durkheim e dos fundadores da escola republicana francesa, muda os conteúdos ensinados e os fundamentos explícitos, mas mantém a pedagogia tradicional dos Jesuítas. Com efeito, ela defende a mesma visão da natureza humana e da criança, embora não fale mais de pecado e de corrupção, mas de selvageria e de indisciplina. "A disciplina transforma a animalidade em humanidade", escreve Kant (1966, p. 70) e, novamente, o corpo é o inimigo: a primeira coisa que as crianças devem aprender na escola, explica Kant, é "acostumar-se a ficarem sentadas tranquilamente, obedecendo exatamente o que lhes foi ordenado" (idem, p. 71). Durkheim dá forma social e republicana a essa pedagogia: "a educação tem por objeto superpor, ao ser que somos, ao nascer, individual e associal, um ser inteiramente novo" (DURKHEIM, 1922, p. 63); é o sentimento "da disciplina interna ou externa, (que) foi instituído pela sociedade", que "nos ensina a dominar as paixões, os instintos" (idem, p. 50).

Para disciplinar a natureza selvagem da criança, a pedagogia tradicional institui a norma contra o desejo. É importante entender que se reprimem os desejos da criança não por sadismo ou autoritarismo, mas para elevá-la. Com efeito, a natureza da criança é dupla (CHARLOT, 2013a): por um lado, é uma natureza corrupta ou selvagem, mas, por outro lado, é uma alma redimida por Jesus, na versão religiosa, ou, na versão republicana, um ser de Razão e de Progresso, futuro cidadão. A pedagogia da Norma contra o Desejo só é possível impondo na criança outra forma de desejo: o de salvar a sua alma, o de ser reconhecida na sua dignidade, o de tornar-se adulta.

A corrente pedagógica chamada de "nova" repousa também sobre uma antropologia da natureza humana, mas ela inverte a posição tradicional a partir de pressupostos rousseauistas, românticas e, às vezes, medicais. A natureza da criança é fundamentalmente boa, a criança é inocente, pura e, portanto, podemos e devemos confiar nos seus interesses naturais, na sua espontaneidade, nos seus desejos. Contudo, essa natureza da criança sofre as interferências dos adultos; "a idade adulta é a cristalização, a petrificação", explica Claparède (1964, p. 166). Sendo assim, qual deve ser o método de educação? Maria Montessori responde (1959, p. 63): "satisfazer as necessidades e as leis da vida", sendo que "a criança mesma indica quais são, por suas manifestações espontâneas e seu progresso". A pedagogia nova é uma pedagogia do Desejo contra a Norma adulta. Todavia, bem como a pedagogia tradicional da Norma não pode desistir de todas as formas de desejo, a pedagogia nova do Desejo não consegue prescindir da norma. A própria natureza é convocada pelo pedagogo para decidir quais são os desejos 
legítimos - o que leva, por exemplo, Cousinet a recusar a rádio e o cinema na educação, por não serem desejos verdadeiros da criança. A norma é reintroduzida na pedagogia, também, como regra construída democraticamente pela própria turma dos alunos - com ajuda do adulto. Seja qual a forma da norma, de fato, o adulto aparentemente expulso permanece o pivô da ação pedagógica.

Quer seja "tradicional" ou "nova", a pedagogia clássica é construída sobre fundamentos antropológicos que dizem o que é e o que deve ser o Homem e, logo, o que é e como deve ser educada a criança. Nessa pedagogia, sejam quais forem suas formas, a questão da relação entre Desejo e Norma sempre é o assunto fundamental, trate-se das finalidades da educação, das relações das crianças com outras crianças ou com adultos, ou do próprio ato de ensino-aprendizagem que, ele também, requer mobilização intelectual do aluno, logo uma forma qualquer de desejo e consideração das normas específicas do conteúdo a ser aprendido. Quando não há mais resposta à questão antropológica, ou, pior ainda, quando já não é sequer levantada, a porta está aberta para a barbárie. Podemos tratar seres humanos como se fossem objetos incômodos, suscetíveis de serem eliminados. Quando não há mais norma legítima, por exemplo, quando o aparelho da Justiça é invadido pela política, vigora a luta selvagem de cada um contra todos para impor seus desejos e seus interesses. Quando não há mais espaço para os desejos, por causa da pobreza ou da miséria ou por esmagamento das subjetividades, enfrentam-se por um lado, os sindicatos do crime e, por outro, o discurso fascistoide da violência como remédio contra a violência. A sociedade contemporânea ainda não vive essa situação, mas ela se aproxima dela. Por quê? O que aconteceu? Qual foi e qual é a contribuição da pedagogia, e, de forma mais ampla, do discurso sobre educação para essa tendência?

\section{A situação contemporânea: bricolagem pedagógica e lógica socio- econômica}

Hoje em dia, não há maiores debates pedagógicos sobre educação. A pedagogia tradicional perdeu a evidência e a legitimidade que ainda tinha na década de 50 e no início dos anos 60 do século passado. A pedagogia nova continua sendo uma pedagogia de resistência, local, minoritária. E não existe o equivalente contemporâneo daquele discurso coerente e dominante que foi a pedagogia tradicional e que ambicionou ser a pedagogia nova; nesse sentido, não há uma pedagogia "contemporânea" - mesmo que sempre seja possível, claro, qualificar como contemporâneas, por definição, as práticas atuais. 
Sendo assim, não tem mais regulação antropológica forte das relações entre Desejo e Norma. Todavia, permanece necessário criar e educar crianças e, logo, resolver na prática a questão das relações entre desejos e normas. Fazemo-lo por bricolagem pedagógica e práticas híbridas. Por um lado, essas práticas deixam mais espaço ao desejo e à subjetividade do que antes de 1968; desse ponto de vista, a sociedade contemporânea aproximou-se do polo Desejo. Por outro lado, a vida dos jovens é estruturada e ritmada por uma sequência de provas, que são o equivalente contemporâneo da disciplina tradicional e da norma. As práticas familiares são mais próximas do polo Desejo e as práticas escolares do polo Norma, mas umas e outras são híbridas: liberdade da criança na família, mas "tem limites"; práticas escolares basicamente tradicionais, uma vez que a própria organização do espaço e do tempo escolares e a ênfase sobre a avaliação individual induzem práticas tradicionais, mas o professor abre parênteses de inspiração construtivista, com um pouco de pesquisa, de trabalho de grupo, de Internet etc. As práticas não são mais referidas a grandes princípios pedagógicos e antropológicos, como nos textos dos Jesuítas, de Durkheim ou de Montessori, elas são os efeitos mais ou menos instáveis de bricolagens cotidianas para enfrentar contradições práticas. Ainda há pais ou professores mais "conservadores" e outros mais "modernos", mas isso parece ser um efeito da sua personalidade e das formas como eles veem a vida e não a consequência de uma escolha filosófica e antropológica.

O que aconteceu? Por que e como, em menos de meio século, passamos de uma situação com pedagogia tradicional dominante e pedagogia nova ambiciosa para uma situação de silêncio antropológico e bricolagem pedagógica?

Ao evidenciar a desigualdade social no ato educacional, os trabalhos teóricos contribuíram para uma desvalorização da pedagogia: em 1969, Lourau fala de "ilusão pedagógica"; em 1970, Bourdieu e Passeron criticam a "reprodução" social na escola; em 1976, Charlot publica a "mistificação pedagógica" (CHARLOT, 2013a). Esses trabalhos tiveram um impacto, mas, como sabemos com Marx, não são as teorias que transformam as relações sociais, são mudanças estruturais da sociedade - que as teorias percebem, explicitam, aceleram ou, pelo contrário, combatem. Para compreender a situação pedagógica atual, é preciso entender duas transformações fundamentais, que procedem da mesma lógica socioeconômica e são coerentes entre si, mas que, ao mesmo tempo, tendem a produzir efeitos pedagógicos opostos - daí a hibridez das práticas atuais.

A partir da década de 60 do século XX, a grande maioria das sociedades dá-se como prioridade o desenvolvimento econômico e social. Portanto, na forma socioeconômica contemporânea, o crescimento econômico precisa do consumo e, portanto, do desejo. As sociedades tradicionais eram sociedades da poupança, a sociedade contemporânea é uma sociedade do crédito e da publicidade: enquanto 
a poupança protela a satisfação do desejo mesmo quando há os recursos para saciá-lo, o crédito possibilita satisfazê-lo antes de ter-se o dinheiro para tanto e a publicidade estimulá-lo constantemente. Sendo assim, não é de admirar que a sociedade contemporânea tenha produzido uma legitimação do desejo, proclamada em 1968. Em nossa sociedade, o desejo é legítimo e toda norma que visa a impedir ou controlar a sua satisfação é a priori suspeita ${ }^{4}$. Não se trata de uma escolha moral, mas do efeito ético e ideológico de uma evolução socioeconômica. Essa legitimação do desejo enfraquece todas as formas de autoridade e todos os discursos sobre a virtude educativa da disciplina. Uma sociedade que considera o desejo como legítimo não pode mais ter como referência uma pedagogia da norma e da disciplina, como é a pedagogia tradicional.

Contudo, nessas condições, por que a sociedade contemporânea não adotou a pedagogia nova, pedagogia do Desejo contra a Norma? Aqui entram no debate uma contradição estrutural do capitalismo e a outra transformação fundamental dos anos 1960/70 que nos interessa: a constituição de um mercado escolar.

A tensão entre Desejo e Norma, ou, na versão psicanalítica, entre princípio de prazer e princípio de realidade, é um dado antropológico fundamental: seja qual a organização social, não há vida humana sem desejo ou sem norma. Mas a forma como funciona e se resolve essa tensão varia segundo os tipos de sociedades e, também, de acordo com a classe social. Nas sociedades com estrutura hierárquica forte, onde a posição social é basicamente definida no nascimento e em que a economia é estável ou evolui em ritmo lento, as relações sociais obedecem a normas estritas, a maioria da população vive ou sobrevive em condições de austeridade e, logicamente, vigora uma pedagogia da disciplina, opondo a norma ao desejo. Com o capitalismo e a chegada ao poder da burguesia, a situação muda. Do ponto de vista político, a burguesia precisa afirmar, contra a aristocracia, que todos os homens nascem iguais; assim, o argumento do pecado original e da natureza corrupta perde força ideológica e a pedagogia tem que encontrar outros fundamentos (o progresso, a razão, a cidadania...). Do ponto de vista econômico, o capitalismo, para produzir sempre novos lucros, tem que integrar novas partes da população na esfera do consumo, de tal modo que a pedagogia tradicional anti desejo é cada vez mais interpelada, de Rousseau em 1762, no Emílio, até o movimento de 1968, passando pelas teorias de pedagogia nova do início do século XX. O capitalismo, porém, não visa à satisfação dos desejos, ele procura o lucro, produzido em situações de desigualdade social estrutural; portanto, a classe dominante tem de impor, de forma ou outra, normas que mantêm sua riqueza e seu poder. Assim, o capitalismo precisa ao mesmo tempo da norma e do desejo: à dialética antropológica do desejo e da norma se

4 Obviamente, não estou aqui julgando, muito menos condenando, mas só analisando. 
superpõe ${ }^{5}$ uma tensão socioeconômica e sociopolítica, em uma dialética cujas configurações sociais, ideológicas e pedagógicas variam de acordo com as épocas e os ciclos econômicos.

Na sociedade contemporânea, a contradição potencial entre desejo e norma é cada vez mais gerida pelo próprio mercado, conforme a lógica neoliberal dominante. $\mathrm{O}$ mercado acolhe todos os tipos de desejo possíveis e imagináveis, inclusive nas áreas outrora tabus da religião e da sexualidade. Cada um pode "escolher" o tipo de comida, de entretenimento, de igreja e de parceiro sexual que melhor lhe convier. Ainda intervêm normas éticas, religiosas, estéticas, mas é cada vez mais o mercado que determina quais desejos serão efetivamente satisfeitos - diretamente, com base nos recursos financeiros que temos, ou indiretamente, a partir das redes em que somos socialmente inseridos. Quando o próprio mercado, isto é, a relação entre oferta e procura, decide a norma, as outras formas de regulação (ética, estética, religiosa, ideológica etc.) perdem força e não existe mais essa fundamentação e totalização das várias normas que uma definição antropológica do ser humano proporciona. Sendo assim, cada um tem que produzir as suas bricolagens psicológicas, éticas, ideológicas, estéticas, pedagógicas etc. Nunca antes na história, o indivíduo foi tão livre e, provavelmente, nunca o sujeito foi tão abandonado a suas próprias bricolagens normativas.

Nessas mesmas décadas de 1960/70 em que a sociedade contemporânea libera o desejo, ela constrói um mercado escolar. Com efeito, o desenvolvimento econômico e social requer uma elevação do nível de formação da população, começando pelos jovens. Já na década de 60 , as sociedades universalizam o ensino primário onde isso ainda não tinha sido feito e abrem para todos quatro anos de ensino fundamental maior ${ }^{6}$. A partir da década de 1980, os países mais modernos tentam também escolarizar todos os jovens no ensino médio. Daí em diante, "todos" os jovens entram na escola, por ao menos nove anos e, nos países mais ricos, por quinze anos (dos 3 aos 18 anos). Assim, já não é o fato de ter sido escolarizado ou não que produz uma diferença na inserção profissional e social do jovem, e sim a série que ele atinge, em qual tipo de escola e se ele entrou no ensino superior. Os jovens encontram-se, assim, engajados em uma grande corrida escolar, regida por uma impiedosa lógica da performance e da concorrência - forma escolar do "livre mercado" neoliberal. Os jovens são livres,

5 A lógica neoliberal não faz desaparecer completamente a questão antropológica, ela a reduz à antropologia mínima que define o ser humano pela procura do seu interesse próprio, na tradição de Adam Smith. Mas não se pode fundamentar uma pedagogia sobre uma definição do homem que o enclausura no solipsismo da solidão ou que o lança na concorrência universal de todos contra todos.

6 Três no Brasil, com regularização para quatro em 2010. 
eles não têm mais que aguentar o peso de um monte de normas impostas pelos adultos, desde que... estudem, estudem, estudem, para preparar as provas, tirar notas boas e, um dia, entrar na universidade. Quanto aos pais, a questão que eles devem resolver não é mais "para qual forma de humanidade devo educar essa criança?", mas "o que fazer para que ela tenha um bom emprego mais tarde?".

A pedagogia tradicional, pedagogia da norma, funciona mal em uma sociedade onde o desejo adquiriu legitimidade. Mas a pedagogia nova, pedagogia do desejo, não a pode substituir em uma sociedade onde notas, provas e concorrência generalizada passaram a ser os novos instrumentos da disciplina social. Não surgiu uma pedagogia "contemporânea" que pudesse ultrapassar essas contradições e, no cotidiano, pais e docentes sobrevivem com bricolagens pedagógicas. Tal situação induz uma crise de sentido à qual cada um responde como pode: pela depressão, pela droga, pelo smartphone, pelo fanatismo, pelo ódio dos imigrantes, pelo fascismo ou, ao contrário, pela militância para um mundo melhor. A porta fica aberta para a volta da barbárie, mas também para pensar em um outro mundo possível e, logo, outras formas de educar as crianças.

\section{Qualidade da educação, "neuroeducação", "cibercultura", "transhumanismo": a questão do Homem em alguns discursos novos}

Não foi construída uma pedagogia "contemporânea", mas novos discursos que apareceram merecem alguma atenção. Evocarei, do ponto de vista da questão antropológica que nos interessa aqui, e de forma inevitavelmente breve no espaço de um artigo, quatro deles, cujos objetos são a "qualidade da educação", a "neuroeducação", a "cibercultura" e o "transhumanismo".

\section{A questão da "qualidade da educação"}

Elaborado pela Organização de Cooperação e Desenvolvimento Econômico (OCDE) nos anos 80 do século $\mathrm{XX}$, o discurso sobre a qualidade da educação substituiu rapidamente os debates dos anos 70 sobre o fracasso escolar dos jovens de meio popular. Este último tema sobrevive quando se fala de "qualidade e equidade" da educação, mas já não se trata, como nos anos 70, de 
uma reivindicação sociopolítica para mais igualdade, mas de uma preocupação econômica com o custo do fracasso, em especial da repetência de ano pelo aluno.

Levantar a questão da qualidade da educação é interessante, mas mais interessante ainda seria uma resposta antropológica: qual homem, e qual mulher, uma "educação de qualidade" deve educar? Infelizmente, não é assim que a questão é tratada. Atualmente, ela é discutida a partir de indícios e classificações, com um enorme risco de círculo vicioso. Por exemplo, na pesquisa internacional PISA, avaliam-se as performances dos alunos de 15 anos em língua maternal, matemática e ciências e os países que obtêm os melhores resultados (Finlândia, Coreia do Sul, Singapura...) são tidos como aqueles onde a educação é melhor. Ou seja: a qualidade da educação é definida pelos resultados da pesquisa sobre a qualidade da educação! Não se trata de negar o sério dessa pesquisa, mas de chamar a atenção para o fato de que a educação é reduzida à aprendizagem e esta é avaliada em apenas três disciplinas. Bem como as avaliações feitas no Brasil pelo SAEB só se importam pelo português e a matemática. História, Filosofia, Arte, Educação Física, consciência ecológica, educação contra todas as formas de discriminação etc.? São excluídas das avaliações da "qualidade da educação"! Sendo assim, os discursos sobre essa qualidade repousam sobre uma representação empobrecida do ser humano e da sua educação e, na verdade, encenam uma concorrência internacional na aprendizagem de disciplinas consideradas economicamente lucrativas.

\section{As neurociências e a "neuroeducação"}

O discurso apoiado em argumentos neurocientíficos espalhou-se nos anos 2000/2010 e está na moda. Para entender seu significado, é preciso distinguir as próprias neurociências e o discurso sobre "neuroeducação".

As neurociências produzem conhecimentos úteis para melhor entender os processos educacionais - mais ainda quando se trata de pessoas sofrendo dificuldades neurológicas como a dislexia. Por exemplo, é interessante saber que a zona cerebral occipito-temporal esquerda, mais mobilizada na aprendizagem da leitura, mantém estreitas relações com aquela que cuida da interpretação dos sons. Esse resultado de pesquisa possibilita melhor entender por que o processo básico da aprendizagem da leitura é a decodificação dos sinais escritos (grafemas) em sons (fonemas), mesmo que seja também importante a interpretação do sentido, assumida por outras áreas cerebrais (DEHAENE, 2007). Assim entendidas, as neurociências contribuem para as ciências da educação. 
Contudo, hoje em dia, muitas vezes elas são usadas como álibis para apresentar ao público conferências e livros sobre "neuroeducação", que não são nada científicos e que constituem o que se pode chamar, com alguma ironia, um "neurocharlatanismo" - denunciado pelos próprios pesquisadores em neurociências. A análise revela três processos. Em primeiro lugar, constatamos uma extensão do discurso além do campo científico, chegando mesmo a falar de neurônios da bondade, de "neuroestética", de "neurofilosofia" e até de "neuroteologia": os valores humanos tornam-se simples efeitos neuronais. Em segundo lugar, observamos um marketing neuronal: depois de apresentar considerações ultra técnicas sobre o cérebro, o autor avança pseudo conclusões pedagógicas que, na verdade, não têm nada a ver com o texto anterior; nesse caso, a referência aos neurônios é utilizada para vender uma mercadoria pedagógica preexistente. Por fim, a análise evidencia, de novo, uma dupla redução: da educação à aprendizagem e desta ao funcionamento dos neurônios. Ocorre, assim, uma redução antropológica da espécie humana ao homem neuronal e, logo, um empobrecimento da representação do homem. Aliás, a própria noção de "neuroeducação" é abusiva, uma vez que a educação visa a finalidades, que não podem ser definidas pelo funcionamento de neurônios.

\section{As novas tecnologias de informação e comunicação e a "cibercultura"}

Os discursos sobre a "qualidade da educação" e sobre a "neuroeducação" veiculam uma concepção empobrecida do ser humano e tendem a reduzir a educação à aprendizagem. Consequentemente, o principal objetivo da política de "qualidade" e dos discursos sobre a "neuroeducação" é melhorar a eficácia da aprendizagem. Sendo assim, esses dois tipos de discursos combinam bem com uma lógica da performance descuidando da questão antropológica.

O caso dos discursos sobre as chamadas novas tecnologias de informação e comunicação (NTIC) e a "cibercultura" é mais complexo e mais interessante do ponto de vista antropológico. Muitos desses discursos, claro, inscrevem-se também numa lógica da performance: nesse caso, sua principal preocupação é aumentar a produtividade do ato de ensino-aprendizagem. Mas as NTIC introduziram irreversíveis formas de modernidade em nossa vida cotidiana e uma reflexão sobre uma pedagogia contemporânea não pode deixar de levá-las em consideração. Ademais, além de possibilitar práticas pedagógicas inovadoras, elas fecham a era do "professor de informação" e estendem a era do "professor de saber". O professor de informação é aquele cujo ensino acumula os dados 
sem se preocupar muito com o sentido que esses dados têm pelos alunos. Hoje, esse tipo de professor está ultrapassado: nenhum vence a concorrência com o Google quando se trata apenas de transmitir informações. O saber, porém, é mais do que informação: são dados verificados, analisados, agrupados, que constituem sistemas ou redes de sentido, que possibilitam resolver problemas, entender fenômenos complexos etc. O professor só sobreviverá tornando-se cada vez mais professor de saber; se ele insistir em permanecer professor de informação, será substituído por dispositivos informáticos e audiovisuais administrados por tutores e monitores e disponibilizados por grandes empresas com finalidades lucrativas.

Além da questão do uso das NTIC, a noção de "cibercultura" nos interessa aqui porque ela apresenta uma dimensão antropológica, bem analisada por Pierre Lévy (1997). De acordo com Lévy, no ciberespaço, isto é, no espaço de comunicação aberto pela interconexão mundial dos computadores e das memórias informáticas, está sendo construída uma "cibercultura". "A "cibercultura" dá forma a uma nova espécie de universal: o universal sem totalidade" (LÉVY, 1997, p. 141), ela mostra que "existe outro modo de instaurar a presença virtual a si mesma da humanidade (o universal) que não a identidade do sentido (a totalidade)" (LÉVY, 1997, p. 143). Enquanto no mundo da escrita o universal só existe com um sentido determinado (na religião, na filosofia, na ciência), o novo universal é "indeterminado", "vazio, sem conteúdo particular, ou, antes, ele aceita todos" (LÉVY, 1997, p. 129). Essa ideia de que a humanidade deixa de ser apenas uma representação e passa a ser presente a si mesma no ciberespaço é pertinente e expressa bem o fato de que, hoje em dia, graças à Internet, o que acontece em um cantinho do mundo pode ser conhecido "em tempo real" e até provocar mudanças no outro lado do planeta. Além disso, essa humanidade por comunicação universal tenta levar o oposto à lógica da concorrência generalizada. Portanto, trata-se de uma ideia importante para pensar a dimensão antropológica de uma pedagogia contemporânea.

Todavia, ele esbarra em dois argumentos. Em primeiro lugar, a realidade observável vinte anos depois de Lévy publicar seu livro é bem diferente do retrato épico desenhado no livro. O ciberespaço como lugar de criatividade e "suporte de inteligência coletiva" (id., p. 33)? Mas o principal uso pedagógico da Internet pelos alunos é o "copiar-colar" na realização das tarefas de casa e as taxas de fracasso no ensino à distância são altíssimas. A "cibercultura" "na continuidade dos ideais revolucionários e republicanos de liberdade, igualdade e fraternidade" (LÉVY, 1997, p. 302)? Mas a Internet está cheia de manobras escuras, insultos, calúnias, fakenews, longe daquele universal fraternal celebrado por Pierre Lévy.

Além disso, a ideia de universal sem totalidade tropeça em uma dificul- 
dade teórica. Qual pode ser o conteúdo das trocas de experiências e ideias na Internet? Se a comunicação só vale por si mesma, ou seja, se apenas se trata de falar por falar, acontece de novo um empobrecimento da representação do ser humano, homo comunicans tão vazio quanto a sua comunicação, uma sombra de ser humano sem nada de importante para dizer. Se "o universal aberto, sem totalidade, da "cibercultura" acolhe e valoriza as singularidades" (LÉVY, 1997, p. 286), ou seja, se, no ciberespaço, cada um pode comunicar suas singularidades ao mundo inteiro, resta saber como advieram essas singularidades. Elas não foram construídas apenas no ciberespaço, mas, antes de tudo, nas relações com pais, irmãos, amigos, colegas, namorados/as etc., naquele mundo real em que é preciso negociar seus desejos com normas de que não se pode fugir por um simples clique. A existência de um ciberespaço como nova forma de presença a si mesma da humanidade é um fato importante a ser levado em conta para refletir numa pedagogia contemporânea, mas a "cibercultura" não define essa pedagogia, nem pode ser seu norteador. Com efeito, ela mesma não resolve a questão pedagógica fundamental, a da relação entre Desejo e Norma. Bem pelo contrário, ela requer que essa questão seja resolvida ou, pelo menos, levantada, para não ser uma forma vazia ou não se tornar o novo palco da barbárie verbal.

\section{O discurso transhumanista}

A palavra "transhumanismo" apareceu na ficção científica no fim dos anos 50 do século XX, mas o "transhumanismo" enquanto movimento filosófico desenvolveu-se na década de 80, a partir de Los Angeles. Em 1998, Nick Bostrom fundou uma Associação Transhumanista Mundial (hoje conhecida como Humanity+ ou H+). Ray Kurzweil propôs uma versão radical de "transhumanismo" com a Universidade da Singularidade, na Califórnia. Depois de ser tratado como uma originalidade divertida, o "transhumanismo" passou a ser levado a sério, discutido, analisado, criticado (BESNIER, 2010, 2012; MAGNIN, 2017). Ele se apoia em argumentos oriundos das NBIC (Nanotecnologias, Biotecnologias, tecnologias da Informação, ciências Cognitivas): nanomedicamentos navegando no sistema sanguíneo para tratar um tumor específico, nanochips implantados no cérebro, terapias génicas, próteses comandadas diretamente pelo cérebro etc. $\mathrm{O}$ grande sonho é baixar o conteúdo do cérebro para uma máquina ou um robô, sendo assim livrado do corpo humano perecível. Paralelamente, a robótica progride e produz androides que reagem aos gestos humanos, reconhecem as entonações da voz, falam, imitem emoções como alegria e tristeza etc. Sendo 
assim, o "transhumanismo" considera que chegou o tempo do ciborgue, do homem biônico. Isso não quer dizer que a máquina ou o robô vai destruir a espécie humana, mas que a diferença está desaparecendo aos poucos: a atual espécie humana vai deixar o lugar para um pós-humano, um homem "aumentado", uma "singularidade" (anunciada por Kurzweil para 2045). Está se esgotando o tempo do sofrimento, da doença, da velhice e, talvez, até o da morte; alguns "transhumanistas" afirmam que já nasceu a geração que viverá até trezentos anos; outros visam à abolição completa da morte, graças às células-tronco. Assim, fica respondida de forma radical a nossa questão antropológica sobre a educação: não tem mais ser humano e, portanto, desaparece a questão antropológica; o pós-humano não é educado, é fabricado e, portanto, acabou também a questão pedagógica.

Podemos colocar três questões a esses discursos. É possível? É desejável? De qual humano ou pós-humano se trata? Separadamente, muitas técnicas evocadas pelo "transhumanismo" já existem ou serão dominadas em breve, mas usá-las juntas para criar um pós-humano é outro assunto. Além do mais, essas técnicas têm um custo alto. Como serão escolhidos, entre os 9,8 bilhões de seres humanos previstos para até 2050, aqueles que se tornarão pós-humanos? Quanto à imortalidade ou à vida de trezentos anos, mesmo com uso de células-tronco, grandes são as dúvidas entre os biologistas; até agora, o recorde de tempo de vida reconhecido é 122 anos e 164 dias (Jeanne Calment) e muitos cientistas pensam que não é possível ultrapassar 130 anos. Aliás, a imortalidade é mesmo desejável? Deve ser muito chato, responde, no jornal Libération (16/08/2018), Jacques Testard, o primeiro cientista a ter realizado uma fecundação in vitro. Magnin lembra que Lacan explicava que um homem imortal seria incapaz de amar e iria se tornar louco, por falta de limites e de vulnerabilidade (2017, p. 83); e ele mesmo escreve: "A morte é uma grande provação pela qual se passa mas não é um erro a ser retificado ou uma derrota do humano" $(2017$, p. 83). Por fim, de qual pós-humano se trata? Com qual corpo vivo, qual história, quais emoções, qual imaginação, qual forma de subjetividade? E, portanto, com quais desejos e qual capacidade de adaptação além de normas pré-programadas? Trata-se mesmo de um homem "aumentado", ou, pelo contrário, simplificado, empobrecido?

A resposta deve ser prudente - já que me ensinaram, outrora, que nunca um computador iria ser capaz de vencer o homem no xadrez... No entanto, no fim dessas análises sobre os novos discursos contemporâneos, podemos avançar duas conclusões sólidas. Em primeiro lugar, se a questão da diferença entre o homem e a máquina (o computador, o robô etc.) está levantada hoje, não é apenas porque a máquina é cada vez mais aperfeiçoada, é também porque se multiplicam as tentativas para reduzir o próprio homem a uma máquina - uma 
máquina de aprender e de comunicar, em um espaço globalizado regido por uma lógica da performance e da concorrência. A segunda conclusão é que o homem está cansado dele mesmo. Os séculos XVIII e XIX anunciaram um novo homem, o do Progresso; os séculos XIX e XX fizeram revoluções sociopolíticas com o sonho de criar "o homem novo"; no nosso século XXI, o "transhumanismo" proclama o fim da nossa espécie e o advento de uma nova, biotécnica. Nesse ambiente de "vergonha prometeica" que Günther Anders já tinha percebido em 1958 (apud BESNIER, 2010, p. 75), não está sendo construída, obviamente, uma pedagogia contemporânea com fundamentos antropológicos. Só acontecem adaptações à contemporaneidade tecnológica, com momentos de depressão, ataques de fundamentalismo religioso ou nacionalista, acessos de ódio, filmes com vampiros, lobisomens e zumbis, resumidamente: volta da barbárie. Mas podemos também rejeitar a tese da morte do homem e seguir sonhando um outro mundo possível. Com quais pontos de apoio antropológicos?

\section{Alguns ensinos da ciência contemporânea sobre o cérebro, os genes e a evolução}

O que a ciência contemporânea nos ensina sobre o homem? Obviamente, não dá para responder a essa questão de forma completa no espaço de um artigo, mas algumas ideias merecem atenção especial.

Em primeiro lugar, o funcionamento do cérebro não tem nada a ver com a representação ingênua de alguns neurônios que tornam alguém mais ou menos inteligente (LLEDO, 2017). O cérebro tem 86 bilhões de neurônios, sendo que cada um deles tem contato com 1000 a 10000 outras células. Ele não funciona por ação isolada de cada neurônio, mas por módulos: cada módulo envolve milhares e às vezes milhões de neurônios. Geralmente, vários módulos trabalham ao mesmo tempo, de forma paralela e, portanto, o cérebro não é um computador, que funciona de modo linear, sequencial; pelo contrário, hoje em dia, o cérebro serve como modelo para tentar construir computadores neuronais. O erro da "neuroeducação" e do "transhumanismo" é precisamente o de pensar o cérebro como se fosse um computador, enquanto é, sim, um sistema dinâmico complexo. Por fim, o cérebro fica em constante troca, emitindo e recebendo, com um corpo e com um meio sociocultural. Bem como, hoje em dia, a partir da fenomenologia, recusamos a dizer "eu tenho um corpo" e afirmamos "eu sou meu corpo", podemos dizer "eu sou meu cérebro" - isto é, também e indissociavelmente, um sujeito cerebral, corporal, psíquico, social, engajado numa história. 
Quando a criança nasce, ela não está terminada. Seu cérebro tem quase o mesmo número de neurônios que o do adulto, e até um pouco mais, mas o que possibilita o pensamento são as sinapses, isto é, as conexões eletroquímicas entre os neurônios. No recém-nascido, apenas 20 a $25 \%$ dos neurônios são conectados. Depois do nascimento acontece um duplo fenômeno. Por um lado, criação de sinapses, particularmente intensa entre 1 e 3 anos, mas que continua durante a vida toda. Em segundo lugar, desconexão de sinapses disponíveis e não utilizadas. Conexão e desconexão dependem das relações do cérebro com o corpo e o meio ambiente. $\mathrm{O}$ desenvolvimento do cérebro e, de forma mais geral, do ser humano, é epigenético, como insiste a genética contemporânea: o ser humano é programado geneticamente, mas o que foi programado aparece e desenvolve-se de acordo com as condições proporcionadas pelo meio. Assim, o homem é programado para falar, enquanto um chimpanzé não falará, mesmo que seja educado exatamente como uma criança humana; mas uma criancinha abandonada na floresta, se ela sobreviver e for encontrada mais tarde, não fala, por não ter crescido num meio humano.

De forma mais geral, temos de nos livrar da ideia de que um gene define um comportamento, como se fosse uma coisa física cuja ação gerasse efeitos; um gene é uma informação codificada num segmento de DNA, numa sequência de nucleotídeos. O ser humano tem mais de 20.000 genes (o número exato, ainda em debate, fica entre 20000 e 25000 ). No início, todas as células são idênticas e contêm a mesma informação genética, mas essa informação é ativada ou não de acordo com a função da célula no organismo e com os sinais que ela recebe do meio. "O vivo escapa ao determinismo genético pela porta da epigênese, isto é, a regulação da expressão gênica de acordo com o comportamento, os hábitos ou as condições de vida" (LLEDO, 2017, p. 58).

O ser humano não é dado, tampouco se constrói sobre uma tabula rasa, ele é geneticamente cultural e culturalmente genético. Sob outra forma, cada um de nós é uma aventura. Chegamos à mesma conclusão quando analisamos o ser humano como espécie, com base na paleoantropologia contemporânea (PICQ, 2005; HUBLIN, 2011). A evolução do australopiteco ao Homo sapiens não é a história de um progresso que iria inevitavelmente conduzir a mim, via Homo habilis e Homo erectus. Em primeiro lugar, não é uma história linear, mas sim em mosaico. A bipedia, o uso de ferramentas, o crânio volumoso e até a comunicação por sinais, isto é, as características consideradas como próprias do homem, além de não ser tão próprias assim, não se desenvolveram todas ao mesmo ritmo: uma espécie pode ser mais avançada de certo ponto de vista e menos de outro ponto de vista. Não aconteceu uma marcha triunfal para sapiens - cujo crânio de $1350 \mathrm{~cm}^{3}$, aliás, é menor do que o de Neandertal $\left(1600 \mathrm{~cm}^{3}\right)$. Em segundo lugar, várias espécies ou subespécies humanas existiram na Terra no 
mesmo momento. Assim, os primeiros homens (Homo ergaster, primeira forma de erectus) conviviam, 1,7 milhões de anos atrás, com duas espécies humanas arcaicas (Homo rudolfensis e Homo habilis) e duas espécies de parantropos (primos dos australopitecos e dos homens). De mesmo modo, 40000 anos atrás, sapiens, que acabava de chegar, compartilhava a Europa com Neandertal (que ainda iria conviver com ele por mais de 10000 anos) e, em outros lugares, viviam os denisovanos (na Sibéria) e provavelmente outros descendentes de erectus na África, na China e na Indonésia. Enquanto existe uma centena de espécies de macacos e já existiram várias espécies ou subespécies humanas, ficamos sozinhos: somos a última espécie de um gênero Homo em extinção.

Desses ensinos da paleoantropologia, podemos tirar duas conclusões opostas. Podemos concluir que decididamente, o homem não tem valor: de acordo com os antropólogos, não há "próprio do homem" claramente definido, somos uma espécie viva (quase) como outras e, ademais, um gênero em extinção. Mas podemos também - como eu prefiro - concluir que somos os resultados de uma aventura improvável, sobreviventes resistentes e frágeis de uma evolução longa e impiedosa, capazes ao mesmo tempo de sair do planeta e de destrui-lo, herdeiros e inventores de desejos e de normas. Existimos graças a golpes de sorte biológicos e climáticos, mas também graças à nossa inteligência coletiva e, fundamentalmente, à educação, que possibilita que cada geração desfrute as conquistas de todas as gerações anteriores. Vale a pena continuar essa aventura, a da espécie, a de grupos sociais e culturais, a de cada um de nós na sua vida singular? Podemos confiar os próximos episódios da aventura à lógica neoliberal da concorrência, mas, neste caso, talvez as fantasmagorias "transhumanistas" sejam proféticas: estamos nos aproximando do fim da aventura de sapiens. Podemos também apostar em um novo projeto antropológico, em que a educação articule os três processos de humanização, socialização e singularização numa lógica de solidariedade e de respeito à dignidade de todos (CHARLOT, 2013b).

A barbárie desenvolve-se quando não reconhecemos o ser humano como aventura singular e coletiva, quando tratamos como objeto, máquina, computador ou fantoche religioso ou ideológico esse extraordinário organismo biopsicocultural e histórico que um ser humano é. O antônimo de barbárie é educação, com os valores de solidariedade e de dignidade que possibilitam a aventura humana, nas suas formas universais, culturais e singulares. Numa sociedade da solidariedade e da dignidade, o que queremos transmitir e ensinar aos jovens? Qual patrimônio, quais forças criativas, quais formas de ser um ser humano, quais relações entre nossa comum humanidade e as diferenças culturais construídas ao longo da história, quais formas de prazer (já que o prazer também se ensina), quais normas? Quais práticas sociais e pedagógicas contra-hegemônicas podem 
produzir solidariedade e dignidade numa sociedade cuja lógica dominante é aquela da concorrência generalizada? Nas nossas escolas, quais práticas (em particular, quais práticas de avaliação) são humanas e quais são formas bárbaras de tratar os alunos? E de tratar os professores? Afinal de contas, qual é nossa antropologia pedagógica prática? A do mais forte e do predador ou a da construção coletiva e solidária de humanidade?

\section{REFERÊNCIAS}

BESNIER, J.-M. Demain les posthumains. Le futur a-t-il encore besoin de nous? Paris: Fayard, 2010.

BESNIER, J.-M. L'homme simplifié. Le syndrome de la touche étoile. Paris: Fayard. 2012. BOURDIEU, P.; PASSERON J.-C. La Reproduction. Paris: Éditions de Minuit, 1970. CHARLOT, B. A Mistificação pedagógica. Nova tradução. São Paulo: Cortez, 2013a. CHARLOT, B. Da relação com o saber às práticas educativas. São Paulo: Cortez, 2013b. CLAPARÈDE, É. Psychologie de l'enfant et pédagogie expérimentale. Tome I. Le développement mental. Paris: Delachaux et Niestlé, 1964.

COUSINET, R. L'éducation nouvelle. Paris: Delachaux et Niestlé, 1968.

DEHAENE, S. Les Neurones de la lecture. Paris: Odile Jacob, 2007.

DURKHEIM, É. Educação e Sociologia. Tradução Dr. Lourenço Filho. 2 ed. São Paulo: Ed. Melhoramentos, 1922.

HUBLIN, J.-J. Quand d'autres hommes peuplaient la Terre. Paris: Flammarion, 2011.

KANT, E. Réflexions sur l'éducation. Paris: Vrin, 1966.

LÉVY, P. Cyberculture. Paris: Odile Jacob, 1997.

LLEDO, P.-M.. Le cerveau, la machine et l'humain. Paris: Odile Jacob, 2017.

LOURAU, R. L'illusion pédagogique. Paris: ÉPI, 1969.

MAGNIN, T. Penser l'humain au temps de l'homme augmenté. Paris: Albin Michel, 2017.

MONTESSORI, M. L'esprit absorbant de l'enfant. Paris: Desclée de Brouwer, 1959.

PICQ, P. Les origines de l'homme. Paris: Tallandier, 2005.

ROUSSEAU, J.J. Emílio ou da Educação. São Paulo: Martins Fontes, 2014. 
SNYDERS, G. La pédagogie en France aux XVII et XVIII" siècles. Paris: P.U.F., 1965. TESTARD, J. Le transhumanisme est une idéologie infantile. Libération, 16/08/2018.

Texto recebido em 16 de outubro de 2018. Texto aprovado em 06 de novembro de 2018. 